\title{
Indigenous Rights
}

\section{and the 1991-2000 Australian Reconciliation Process}

\author{
Andrew Gunstone
}

\begin{abstract}
The formal reconciliation process in Australia was conducted between 1991 and 2000 and aimed to reconcile Indigenous and non-Indigenous peoples by 2001. In this paper, I detail the failure of both this reconciliation process and governments, in particular the Howard Government, to recognise Indigenous rights, such as sovereignty, a treaty, self-determination and land rights.
\end{abstract}

In 1991, the Australian Commonwealth Parliament unanimously passed the Council for Aboriginal Reconciliation Act 1991 which instituted a ten-year formal process of reconciliation. The aim of this process was to reconcile Indigenous and non-Indigenous peoples by the centenary of Australia's federation in 2001. The process was facilitated and promoted by the government-initiated Council for Aboriginal Reconciliation (CAR).

During the reconciliation decade, many Indigenous political leaders, involved in key Indigenous organisations, such as CAR or the Aboriginal and Torres Strait Islander Commission (ATSIC), and who were mostly men, consistently and clearly advocated that a range of Indigenous rights needed to be genuinely recognised by the reconciliation process and governments. These rights included sovereignty, self-determination, land rights, intellectual and cultural rights, parliamentary representation and a treaty. In this paper, I detail this history of political demands for Indigenous rights by Indigenous leaders between 1991 and 2000. I argue that these demands, despite their consistency and clarity, were largely not addressed by the conclusion of the reconciliation process, either by several key documents published by CAR in 2000, in particular the Documents of Reconciliation, or by Australian governments.

Early in the reconciliation process, many Indigenous leaders were very sceptical of the concept of reconciliation and saw the process as a stalling tactic by the Hawke Government 
to avoid discussions of Indigenous rights, such as a treaty and sovereignty. Kevin Gilbert, poet and author, at a 'Day of Protest and Mourning' at the Aboriginal Tent Embassy, held on the 27 May 1992, argued:

We have seen the Australian Government and the Australian people try to get off the hook of responsibility by saying, ten years down the track, we'll have Reconciliation. And Reconciliation doesn't promise us human rights, it doesn't promise us our Sovereign rights or the platform from which to negotiate, and it doesn't promise us a viable land base ... It is ten more years of death! (cited in Attwood \& Markus 1999, pp.321-322)

Bundjalung elder Reverend Frank Roberts, was likewise very critical of the concept of reconciliation. He wrote that a meeting of the Far North Coast NSW Aboriginal Elders Council:

rejected outright the concept of reconciliation at this point in time, believing it is mistimed and premature and would put unborn Aboriginal people in jeopardy. It would only be a token gesture .... To even contemplate reconciliation now would be an act of betrayal. If we reject reconciliation, then a treaty is a must (Roberts 1992, p.5).

Other Indigenous leaders also expressed reservations about the reconciliation process. Paul Coe, from the NSW Aboriginal Legal Service, stated, 'why should justice for Aboriginal people be delayed till the oppressor is “enlightened” in its attitudes?' (cited in Duke 1992, p.6). Charles Harris, a retired minister and activist, contended that the initial step in the reconciliation process must be the addressing of 'the just demands of the people. Land rights, sovereignty, etc. must be dealt with' (cited in Wilson 1991, p. 13). In 1994, Michael Mansell, an Indigenous activist and a strong advocate for Indigenous sovereignty, argued that in its first few years, the reconciliation process had not shown a desire to work towards changing power relations (Mansell 1994, p.15).

The Chairperson of CAR from 1991 to 1997 and the person regarded as the 'Father of Reconciliation', Pat Dodson, similarly advocated the importance of Indigenous rights. Early on in the reconciliation process, Dodson stated that the reconciliation process needed to implement a document of reconciliation and to consider a broad range of issues, including 
sovereignty, constitutional change, Indigenous rights and 'power sharing' (Dodson 1992a, pp.9-11; see Mudrooroo 1995, p.233).

Some non-Indigenous people, who supported Indigenous rights, were likewise not initially supportive of reconciliation. For example, author Judith Wright, a key member of the Aboriginal Treaty Committee, wrote that reconciliation was a 'mischievous attempt to fool the rest of the world into thinking something constructive is being attempted' (Wright 1992, cited in Roberts 1993, p.16). Historian Henry Reynolds saw it as a public relations strategy after the policy failures of the 1980s:

it is hard to avoid the conclusion that the process of reconciliation is being pursued because the government must be seen to be doing something, having abandoned the pre-1983 commitment to national land rights legislation and having edged gingerly away from the concept of a treaty promised by the prime minister at Barunga in 1988 (Reynolds 1991, p. 3).

A prominent non-Indigenous ex-public servant and another key member of the Aboriginal Treaty Committee, H. C. Coombs, contended that CAR was not effective in developing reconciliation as

it is not achieving results from the Aboriginal community. They do not, in my view, identify with the process: they are looking for evidence that there is a genuine commitment on the part of the government and on the part of the white Australian community to accept their right to autonomy (cited in Walker 1994, p.14).

The reactions from some Indigenous leaders to the High Court's 1992 judgement in Mabo and Others $v$ Queensland (No 2) also illustrated the importance that many Indigenous people place upon the recognition of Indigenous rights. Although the Mabo judgement recognised the legal fiction of terra nullius and the continuing, albeit severely diminished, existence of Indigenous native title, it reinforced the rights of the Crown. In a previous judgement, the Seas and Submerged Lands Case 1975, the High Court decided: 'The acquisition of territory by a sovereign state for the first time is an act of state which cannot be challenged, controlled or interfered with by the courts of that State' ((1975) 135 CLR 337, 388). Brennan J (with Mason CJ and McHugh J concurring) supported this position in the Mabo judgement when he stated: 'The Crown's acquisition of sovereignty over the several parts of Australia cannot be 
challenged in an Australian municipal court' ((1992) 66 ALJR 453). Incidentally, this position of the High Court was not addressed by the Keating Government's Native Title Act 1993 (Cth).

This aspect of the Mabo judgement was heavily criticised by Michael Mansell who argued that the judgement undermined Indigenous people's campaigns for the recognition of their sovereignty.

The Court was silent on the equally unjust use of the doctrine [of terra nullius] to deny sovereignty. The Court refused to follow precedent on the issue of terra nullius for to do so would be to maintain a legal fiction based on political convenience. Yet the very same convenience was relied on by the Judges to shut the door to any Aboriginal hopes for arguing Aboriginal sovereignty in the Courts (Mansell 1993, pp.4-5; see Reynolds 1998, p.209; Mansell 1992, pp.36-37).

Other prominent Indigenous leaders, such as Noel Pearson, Executive Director of the Cape York Land Council, and magistrate Pat O’Shane, expressed concerns as well regarding the limitations of the Mabo decision (Pearson 1994, p.75; O’Shane 1994, p.29). The failure of the High Court to address sovereignty was further criticised by non-Indigenous historian Henry Reynolds. Reynolds stated that, 'while the courts demolished the concept of terra nullius in respect of property, it preserved it in relation to sovereignty ... [which] lines Australian law up with the international lawyers writing at the high noon of imperialism’ (Reynolds 1996, pp.3, 13).

On 3 June 1999, CAR released its Draft Document for Reconciliation. This contained the Draft Declaration for Reconciliation and the National Strategies to Advance Reconciliation. CAR wrote that it would consult with the wider Australian community about their Draft Document for Reconciliation and would incorporate feedback into a final document for reconciliation that would be presented to the Australian public in May 2000 (CAR 1999, p.4).

Many Indigenous leaders were concerned at the failure of the Draft Document for Reconciliation to specifically mention Indigenous rights, such as sovereignty and a treaty. Geoff Clark, then Chairperson of ATSIC, argued that any document of reconciliation should be a formal agreement between Indigenous people and Commonwealth and State 
governments that should address several key issues, including: the structural relationship between Indigenous people and the Australian state; self-determination; land issues; stolen generations (including an apology and compensation); protection from racial discrimination; customary law; the provision of an independent economic base for Indigenous people; and a treaty (Clark 2000a, p.233). Similarly, Pat Dodson wrote that there needed to be a 'formal document that recognises and guarantees the rights of indigenous Australians within the Australian Constitution' and that this document would 'provide substantial reconciliation' by addressing: equal human rights and specific Indigenous rights; rights of Indigenous people to maintain their distinct characteristics, identities, laws, cultures, spiritual traditions and languages; the right of Indigenous self-determination; Indigenous control over economic and social development; Indigenous ownership of land and resources and just compensation for land that cannot be returned; the right of Indigenous self-government; constitutional recognition; and the enacting of treaties (Dodson 2000, pp.269, 270-273). In 1999, Gatjil Djerrkura, then Chairperson of ATSIC, expressed his concerns with the Draft Document for Reconciliation.

I am pessimistic about the prospects of any document which fails squarely to recognise the principle of self-determination gaining support amongst indigenous constituencies. Further, a significant proportion of Aboriginal people in my country continue to assert our unextinguished sovereignty. It is reasonably clear that indigenous people will not agree to any document or documents of reconciliation which compromise these assertions of sovereignty ... indigenous Australians are unlikely to conclude that the Draft Declaration represents an accurate reflection of our actual aspirations and entitlements (Djerrkura 1999, pp.6-7).

This concern that any final document of reconciliation should incorporate Indigenous rights, such as sovereignty and a treaty, was again demonstrated following the release by the Howard Government of the proposed Constitutional Preamble as part of the November 6 1999 Constitutional Referendum. While CAR saw this proposed Preamble as one possibility for a document of reconciliation and 'a definite step forward for reconciliation' (CAR 1997, p. 4; Scott 1999, p. 17), many Indigenous leaders argued that the Preamble 'fails to recognise the inherent and distinct rights of the first nations which have been recognised by the High Court' (Agius et al. 1999, p. 15; see Mansell 1999, p. 18). A meeting of a number of Indigenous leaders unanimously recommended that the 'question on the draft preamble to the 
Australian Constitution should be dropped from the forthcoming Republic referendum' (Agius et al. 1999, p.15). One of the participants at this meeting, Pat Dodson, later wrote that

all Australians should reject any preamble to our national Constitution that denies the true status of indigenous Australians as the custodians and owners of the land, and suggests that we are nothing more than gardeners at the station homestead (Dodson 2000, p.270).

Just prior to the release of CAR's final document of reconciliation, there were two more significant instances of Indigenous leaders arguing that Indigenous rights should form part of a reconciliation agenda. On 12 May 2000, Pat Dodson stated that CAR should recommend to the Commonwealth Government that a treaty be developed between Indigenous people and the Commonwealth Government (Dodson 2000b, pp.20-21). Dodson contended the treaty should be based on a number of core principles, including: 'political representation, reparations and compensation, regional agreements, Indigenous regional self-government, cultural and intellectual property rights, recognition of customary law and an economic base' (Dodson 2000b, p.19). On May 25 2000, four Indigenous leaders, Geoff Clark, Aden Ridgeway, David Ross and Pat Dodson, with Bill Jonas as an observer, met with Prime Minister John Howard in an attempt to place a number of issues on a post-document reconciliation agenda. These issues included the development of a treaty, the reservation of parliamentary seats for Indigenous people, self-determination, compensation, selfgovernment and customary law (Saunders \& Shanahan 2000, p.5; Saunders 2000, p.1). It was 'the most ambitious plan put to the Prime Minister by Aborigines - imposing a deadline for the enactment of legislation and mentioning government funds to facilitate negotiations' (Saunders 2000, p.1).

At the conclusion of their nine-month consultation process concerning the Draft Document for Reconciliation, CAR developed their final document of reconciliation. To commemorate the occasion, a two-day event entitled Corroboree 2000 was held from 27 to 28 May 2000 at the Sydney Opera House. On the first day of Corroboree 2000, CAR unveiled their Documents for Reconciliation to the Australian community, which consisted of the Australian Declaration towards Reconciliation and the Roadmap for Reconciliation. These documents contained no substantive recognition of Indigenous rights. In fact Pat Dodson 
boycotted Corroboree 2000 in protest at CAR's 'grossly inadequate' documents of reconciliation (Gordon 2001, p.100; Gordon 2000, p.1).

CAR intended the Australian Declaration towards Reconciliation to be an 'aspirational statement' that would be embraced by both non-Indigenous and Indigenous people (CAR 2000a, p.71). The wording of this final version was:

\section{Australian Declaration towards Reconciliation}

We, the peoples of Australia, of many origins as we are, make a commitment to go on together in a spirit of reconciliation.

We value the unique status of Aboriginal and Torres Strait Islander peoples as the original owners and custodians of lands and waters.

We recognise this land and its waters were settled as colonies without treaty or consent.

Reaffirming the human rights of all Australians, we respect and recognise continuing customary laws, beliefs and traditions.

Through understanding the spiritual relationship between the land and its first peoples, we share our future and live in harmony.

Our nation must have the courage to own the truth, to heal the wounds of its past so that we can move on together at peace with ourselves.

Reconciliation must live in the hearts and minds of all Australians. Many steps have been taken, many steps remain as we learn our shared histories.

As we walk the journey of healing, one part of the nation apologises and expresses its sorrow and sincere regret for the injustices of the past, so the other part accepts the apologies and forgives.

We desire a future where all Australians enjoy their rights, accept their responsibilities, and have the opportunity to achieve their full potential. And so, we pledge ourselves to stop injustice, overcome disadvantage, and respect that Aboriginal and Torres Strait Islander peoples have the right to selfdetermination within the life of the nation.

Our hope is for a united Australia that respects this land of ours; values the Aboriginal and Torres Strait Islander heritage; and provides justice and equity for all (CAR 2000c, p.3). 
The Australian Declaration towards Reconciliation failed to address many of the arguments raised by a number of Indigenous leaders, including Dodson, Clark and Djerrkura, following the release of the Draft Document for Reconciliation. It contained no substantive commitments to address Indigenous rights, including land rights, a treaty or sovereignty (Nettheim 2000, p.63). The Australian Declaration towards Reconciliation was a nationalist document, containing phrases such as 'we, the peoples of Australia', 'go on together', 'we share our future and live in harmony', 'move on together' and 'united Australia' (CAR 2000c, p.3). Also, while the term 'self-determination' was used in the Australian Declaration towards Reconciliation, it was linked with the phrase 'within the life of the nation' (CAR 2000c, p.3). As Monk outlined, the term 'self-determination, whilst upheld in the Declaration Towards Reconciliation, was not part of the process of arriving at a document, and has largely been included as a political catch-phrase’ (Monk 2001, p.22). Lastly, the Australian Declaration towards Reconciliation contained a conditional apology. Rather than unambiguously and unconditionally offering an apology to Indigenous people, it merely stated that as 'one part' of the nation apologises, another 'part accepts the apologies and forgives’ (CAR 2000c, p.3). This conditional apology does not belong to a substantial reconciliation process as it was not a genuine apology offered with no conditions that the offended shall forgive the offender (see Gaita 2000, p.286). Overall, the Australian Declaration towards Reconciliation was far removed from what Indigenous leaders had been advocating both before and during the reconciliation process.

In addition to the Australian Declaration towards Reconciliation, CAR presented the Roadmap for Reconciliation at Corroboree 2000. This Roadmap for Reconciliation outlined four national strategies 'identifying ways governments, community groups, organisations and individuals can implement the principles of the Declaration to help improve the lives of Aboriginal and Torres Strait Islander peoples and achieve reconciliation' (CAR 2000a, p.71). These strategies were: the National Strategy to Sustain the Reconciliation Process, the National Strategy to Promote Recognition of Aboriginal and Torres Strait Islander Rights, the National Strategy to Overcome Disadvantage and the National Strategy for Economic Independence. As with the Australian Declaration towards Reconciliation, the Roadmap for Reconciliation failed to address many of the Indigenous rights, including a treaty and sovereignty, that Indigenous leaders had long been advocating, both from within and from outside the formal reconciliation process. For example, the National Strategy to Promote Recognition of Aboriginal and Torres Strait Islander Rights failed to articulate many 
Indigenous rights, including sovereignty and a treaty (CAR 2000b, p.3). The National Strategy to Overcome Disadvantage focussed on socio-economic conditions, such as health, education and employment, instead of looking at broader issues of reparative justice such as sovereignty and a treaty (CAR 2000b, p.5).

Following Corroboree 2000, a number of Indigenous leaders continued to campaign for Indigenous rights, in particular for a treaty. However, many in the wider community failed to see the connection between reconciliation and a treaty. Geoff Clark said he was 'astonished' when a senior journalist asked him, during Corroboree 2000, 'when Aboriginal leaders had decided to place negotiation of a treaty on the reconciliation agenda' (Clark 2000b, p.13). Clark argued that the 'negotiation of a treaty has never been off our agenda' and that the reconciliation process was imposed upon Indigenous people by former Prime Minister Hawke in response to Indigenous demands for a treaty (Clark 2000b, p.13). Clark wrote, 'true reconciliation means recognising we possess distinct rights. They arise from our status as first peoples ... a commitment from the government to negotiate a treaty is essential' (Clark 2000c, p.8). Clark contended that the significant public support for reconciliation shown during Corroboree 2000 illustrated the wider community wanted a 'new deal' for Indigenous people, including a treaty, and was the 'mandate' that Howard claimed he needed in order to negotiate a treaty (Clark 2000b, p.13).

On June 5 2000, a number of Indigenous leaders, including Pat Dodson, Geoff Clark, Noel Pearson, David Ross, Ray Robinson, Gary Foley, Peter Yu, Marcia Langton, Michael Mansell and Charles Perkins, unanimously agreed to continue lobbying for a treaty (Mitchell 2000, p.2). Clark stated 'the meeting has decided that we need to come out with a formal agreement with government to resolve all the unfinished business in this country' (cited in Mitchell 2000, p.2).

These calls for a treaty received some support from the wider community. Former Prime Minister Malcolm Fraser contended a treaty could be useful 'if it helped clear up misunderstandings' (cited in Saunders et al. 2000, p.4). The Labor Federal Opposition and the Australian Democrats indicated they would consider a treaty (Saunders et al. 2000, p.4; Jopson \& Metherell 2000, p.7). The Australian Council of Trade Unions and the Australian Council for Social Services issued a joint statement that "called for "real leadership” to bring such a document into fruition [because] "it’s time for a treaty”' (cited in Saunders et al. 2000, 
p.4). Ronald Wilson, the co-author of the 'Bringing them Home' report into the stolen generations, also supported a treaty (Taylor 2000, p.10). Bryan Keon-Cohen, a prominent lawyer, wrote a treaty would not be a 'radical concept', many other nations have treaties and the Aboriginal Treaty Committee 'laid the groundwork' for a treaty back in the late 1970s and early 1980s (Keon-Cohen 2000, p.17).

However, there was though substantial opposition to these calls for a treaty. This opposition predominantly came from some members of CAR and the Howard Government. The leadership of CAR both disputed the claims of many Indigenous leaders that the public support shown during Corroboree 2000 was a mandate for a treaty and argued that demands for a treaty would 'derail’ reconciliation (Saunders \& Rintoul 2000, p.1; Huggins 2000, p.11). Evelyn Scott, the Chairperson of CAR, claimed discussion of a treaty at this time would 'hurt rather than help take us forward' and further education was required (Saunders \& Rintoul 2000, p.1; Scott 2000a, p.15). Scott attacked the Indigenous leaders advocating a treaty, stating 'who made them leaders? No one has made them leaders' (Nason 2000a, p.1). However, Scott herself was appointed by the Howard Government to be Chairperson of CAR. As well, one of those leaders she criticised was Geoff Clark, who was the first person to be elected the Chairperson of ATSIC. Scott illustrated that she viewed reconciliation and a treaty as separate issues when she contended, 'the treaty will not be advocated in the council's final report (to parliament in December) because we are talking about reconciliation in Australia' (Nason 2000a, p.4). Gustav Nossal, the Deputy Chairperson of CAR, stated the issue was ‘divisive' and could damage the support for reconciliation gained at Corroboree 2000 (Saunders \& Rintoul 2000, p.1). Another CAR member, Jackie Huggins, wrote that while she supported discussions on a treaty, Corroboree 2000 did not provide a mandate for this 'highly emotive' issue and there was a 'need for wide community education and awareness, so that these issues [a treaty and Indigenous parliamentary representation] cannot be turned into divisive diversions’ (Huggins 2000, p.11). Gatjil Djerrkura, a former Chairperson of ATSIC, similarly advocated the push for a treaty could damage reconciliation and that 'a treaty should not be rushed' (cited in Balogh 2000, p.2). Ray Martin, another member of CAR, criticised the campaign for a treaty and promoted a nationalist line by stating that the wider community would not accept 'the idea of special rights or privileges' (cited in Nason 2000a, p.4). 
The Howard Government likewise strongly rejected the campaign for a treaty. This approach was consistent with the Howard Government's strong opposition to Indigenous rights, including self-determination and native title. Howard described the demands for a treaty as 'very divisive’ (cited in Saunders \& Nason 2000, p.1). Howard argued, 'a nation, an undivided nation, does not make a treaty with itself. I mean, to talk about one part of Australia making a treaty with another part is to accept that we are in effect two nations' (cited in Wright \& Taylor 2000, p.2). Saunders and Nason reported that Howard claimed that enacting a treaty could lead to 'national separatism, land claims and litigation' (Saunders \& Nason 2000, p.1).

In addition, the campaign for a treaty was rejected by other conservative political leaders around Australia. The Chief Minister of the Northern Territory, Denis Burke, claimed the 'Aboriginal industry' was 'hijacking' the reconciliation process and that it was a 'disgraceful' attempt to create separate Indigenous states in northern Australia (cited in Nason \& Saunders 2000, p.4). The Premier of Western Australia, Richard Court, expressed similar concerns, stating that 'we don't need a treaty, we are one country. A treaty has the real potential to divide, not unite' (cited in Nason \& Saunders 2000, p.4).

Some Labor premiers were ambivalent about a treaty. The Premier of Queensland, Peter Beattie, refused to commit to a treaty and stated his cabinet would discuss the issue 'to see how it could be effected' (cited in Nason \& Saunders 2000, p.4). The Premier of Victoria, Steve Bracks, similarly did not commit to a treaty and simply stated his Government would 'examine the proposed treaty’ (cited in Nason \& Saunders 2000, p.4).

Another Indigenous right discussed at the May 25 meeting with Prime Minister Howard, namely addressing self-determination through reserving parliamentary seats for Indigenous people, received a similarly negative reaction from political leaders. Howard called the issue divisive and argued, 'a large number of Aboriginal and Torres Strait Islanders would rather see themselves going into parliament as part of the Australian community rather than through some kind of special reservation of parliamentary seats' (cited in Saunders 2000, p.2). The Labor Opposition federal leader, Kim Beazley, also disagreed with the idea and believed that increasing Indigenous parliamentary participation could be achieved in the 'normal way' by political parties encouraging more Indigenous candidates to run for election (cited in Saunders 2000, p.2). 
These reactions by many in the wider community to the idea of Indigenous rights, such as a treaty and reserved Indigenous seats, were criticised by Pratt, Elder and Ellis:

In so wholeheartedly and enthusiastically taking up the idea of reconciliation as the solution to the effects of colonial power relations between Indigenous and non-Indigenous peoples, non-Indigenous peoples often slip quickly and unproblematically from solutions articulated by different Indigenous communities and representatives, to actions that often fail to adequately address them. Calls for a treaty between Indigenous and non-Indigenous people, for example, are often sidelined by government agendas that seek to minimise any shift in power relations between Indigenous and non-Indigenous peoples (Pratt, Elder \& Ellis 2001, pp. 135-136).

On 7 December 2000, the final report from CAR, Reconciliation: Australia's Challenge, was tabled in the Commonwealth Parliament. This report outlined the decade-long history of CAR and the formal reconciliation process. The report made six recommendations to the Commonwealth Parliament concerning the Documents for Reconciliation presented at Corroboree 2000. Of particular relevance to this paper were recommendation five that called on all Australian parliaments to recognize that reconciliation would be advanced through treaties or agreements and recommendation six that called on the Commonwealth parliament to pass legislation (CAR included draft legislation in their report) that would initiate a process to develop an agreement or a treaty (CAR 2000a, pp.105-106). Further, although not specifically mentioned in CAR's final report, the draft legislation developed by CAR included 'a requirement that the Prime Minister commence negotiations with ATSIC to develop a process by way of a treaty or an agreement to address the unresolved issues of reconciliation' (Jonas 2001, p.198). Interestingly, this emphasis by CAR on a treaty in their final report, which was almost entirely lacking during their ten-year existence, was, according to former ATSIC Chairperson, Lowitja O’Donoghue, largely a result of the efforts of Geoff Clark, with the leadership of CAR, Evelyn Scott and Gus Nossal, opposing the reference to a treaty (Nason 2000b, p.5; see Nossal 2000, p.302). In discussing CAR's final report, Scott illustrated her lukewarm view of a treaty, merely commentating that 'we must have a conversation about these issues' (Scott 2000b, p.13).

In December 2000, CAR released four booklets that further detailed the national strategies contained in the Roadmap for Reconciliation. These booklets similarly failed to genuinely 
address Indigenous rights. Overcoming Disadvantage contained over 100 separate actions but generally did not examine rights such as customary law, land rights, a treaty or selfdetermination (CAR 2000d, pp.3-18). Achieving Economic Independence largely did not address alternative entry programs in education, affirmative action in employment or Indigenous rights to their land in accessing capital (CAR 2000e, pp.3-10). Recognising Aboriginal and Torres Strait Islander Rights excluded Indigenous sovereignty in its discussions on self-determination and argued some Indigenous rights could only be advanced 'over the longer term' (CAR 2000f, pp.3, 14). Sustaining the Reconciliation Process recognised, to a limited extent, racism and inequality, yet predominantly focussed on education and symbolism, rather than on Indigenous rights such as a treaty (CAR 2000g, pp.5-8, 23-25).

After a delay of almost two years from CAR's December 2000 report, the Howard Government finally released their response to the report in September 2002. The response was entitled Commonwealth Government Response to the Council for Aboriginal Reconciliation Final Report - Reconciliation: Australia's Challenge and outlined the Government's approach to each of the six recommendations contained in CAR's final report. The most relevant responses of the Government for this paper were those made in regard to the fifth and sixth recommendations. The Howard Government stated that while it supported some agreements, such as Indigenous Land Use Agreements on native title, it did not support the concept of a treaty because

such a legally enforceable instrument, as between sovereign states would be divisive, would undermine the concept of a single Australian nation, would create legal uncertainty and future disputation and would not best harness the positive environment that now exists in reconciliation. In fact, such a process could threaten that environment (Commonwealth Government 2002, p.23).

In this paper, I examined the 1991-2000 formal reconciliation process in Australia and the failure of this process and governments, particularly the Howard Government, to genuinely recognise Indigenous rights. This failure occurred despite numerous Indigenous leaders consistently advocating the need to recognise Indigenous rights, including sovereignty, selfdetermination, a treaty, parliamentary representation, land rights and native title, throughout the reconciliation decade. 
The recognition of Indigenous rights would significantly address one of the key elements of reconciliation - that of justice. However, the 1991-2000 process focussed on other elements of reconciliation, particularly peace, forgiveness and repentance. Subsequently, the reconciliation process, in failing to recognise Indigenous rights and in marginalising the notion of justice, did not achieve its overall aim of reconciling Indigenous and nonIndigenous peoples by 2001 (see Gunstone 2009).

For any future reconciliation process in Australia to have any chance of genuinely achieving a substantive reconciliation between Indigenous and non-Indigenous peoples, the reconciliation process must address the key element of justice by recognising those Indigenous rights that have been demanded by Indigenous leaders for decades.

\section{References}

Agius, P., Ah Mat, R., Djerrkura, G., Dodson, P., Dodson, M., Fry, N., Havnen, O., Mansell, M., O’Donoghue, L., Perkins, C., Ross, D., Tanner, A., and Yu, P. 1999, 'Media release 12 August 1999 - Drop the preamble’, Journal of Australian Indigenous Issues, vol. 2, no. 3, p. 15.

Attwood, B. \& Markus, A. 1999, The Struggle for Aboriginal Rights: A documentary history, Allen and Unwin, Sydney.

Balogh, S. 2000, 'Reconcile now, treaty later', The Australian, 5 June 2000, p. 2.

Clark, G. 2000a, 'Not much progress’ in Grattan, M. (ed), Essays on Australian Reconciliation, Bookman Press, Melbourne.

Clark, G. 2000b, ‘A treaty was always our aim’, The Australian, 30 May 2000, p. 13.

Clark, G. 2000c, 'We must now step up our struggle’, The Age, 29 May 2000, p. 8.

Commonwealth Government 2002, Commonwealth Government Response to the Council for Aboriginal Reconciliation Act 1991 (Cth).

Council for Aboriginal Reconciliation (CAR) 1994, Walking Together: the First Steps Report of the Council for Aboriginal Reconciliation to Federal Parliament 1991-94, AGPS, Canberra.

Council for Aboriginal Reconciliation (CAR) 1997, Walking Together, no. 20.

Council for Aboriginal Reconciliation (CAR) 1999, Draft Document for Reconciliation - A Draft for discussion by the Australian people, Canberra.

Council for Aboriginal Reconciliation (CAR) 2000a, Reconciliation, Australia's challenge Final Report of the Council for Aboriginal Reconciliation to the Prime Minister and the Commonwealth Parliament, Canberra.

Council for Aboriginal Reconciliation (CAR) 2000b, Roadmap for Reconciliation, Canberra. 
Council for Aboriginal Reconciliation (CAR) 2000c, Corroboree 2000: Towards Reconciliation, Canberra.

Council for Aboriginal Reconciliation (CAR) 2000d, Overcoming Disadvantage: Ways to implement the National Strategy to Overcome Disadvantage, one of four National Strategies in the Roadmap for Reconciliation, Canberra.

Council for Aboriginal Reconciliation (CAR) 2000e, Achieving Economic Independence: Ways to implement the National Strategy to Achieve Economic Independence, one of four National Strategies in the Roadmap for Reconciliation, Canberra.

Council for Aboriginal Reconciliation (CAR) 2000f, Recognising Aboriginal and Torres Strait Islander Rights: Ways to implement the National Strategy to Promote Recognition of Aboriginal and Torres Strait Islander Rights, one of four National Strategies in the Roadmap for Reconciliation, Canberra.

Council for Aboriginal Reconciliation (CAR) 2000g, Sustaining the Reconciliation Process: Ways to implement the National Strategy to Sustain the Reconciliation Process, one of four National Strategies in the Roadmap for Reconciliation, Canberra.

Djerrkura, G. 1999, 'Indigenous peoples, constitutions and treaties: A Dialogue on Indigenous Rights in the Commonwealth’, London, 23 July 1999, London Institute of Commonwealth Studies, http://www.atsic.gov.au/issues/indigenous_rights/international /archives/Constitutions_and_Treaties/londonshort_July1999.pdf , accessed September 9 2003.

Dodson, P. 1992, 'Comments on the reconciliation process', Aboriginal Studies Association, vol. 2, no. 1, pp.9-11.

Dodson, P. 2000, 'Lingiari: Until the chains are broken' in Grattan, M. (ed), Essays on Australian Reconciliation, Bookman Press, Melbourne.

Duke, T. 1992, 'Reconciliation ... Who Reckons What!', Twelve to Twenty-Five, vol. 2, no. 2, pp.6-7.

Gaita, R. 2000, 'Guilt, shame and collective responsibility’ in Grattan, M. (ed), Essays on Australian Reconciliation, Bookman Press, Melbourne.

Gunstone, A. 2009, Unfinished Business: the Australian formal reconciliation process ( $2^{\text {nd }}$ edition), Australian Scholarly Publishing, Melbourne.

Huggins, J. 2000, 'Emotional thunder cracks unity’, The Australian, 2 June 2000, p.11.

Jonas, W. 2001, Social Justice Report 2001, Human Rights and Equal Opportunity Commission, Canberra.

Jopson, D. and Metherell, M. 2000, 'Howard stands firm over treaty', The Sydney Morning Herald, 8 December 2000, p.7.

Keon-Cohen, B. 2000, 'The terms of a treaty', The Age, 1 June 2000, p. 17.

Mabo and Others $v$ Queensland 1992, 66 ALJR 408.

Mansell, M. 1992, 'The Court gives an inch but takes another mile' in The Aboriginal Provisional Government Papers, Volume 1, Deep South Sovereign Publications, Hobart.

Mansell, M. 1993, 'Australians and Aborigines and the Mabo decision: just who needs whom the most?' in Hocking, B. (ed), Essays on the Mabo decision, Law Book Company, Sydney. 
Mansell, M. 1994, 'Time for a new approach', The Weekend Australian, 20-21 August 1994, p. 15.

Mansell, M. 1999, 'Forget the Preamble - Give us real rights', Journal of Australian Indigenous Issues, vol. 2, no. 3, pp 18-19.

Mitchell, B. 2000, 'Indigenous leaders persist on treaty’, The Australian, 6 June 2000, p. 2.

Monk, L. 2001, 'Self-determination, Justice and Australia in the new Millennium', Journal of Australian Indigenous Issues, vol. 4, no. 3, pp.13-28.

Mudrooroo 1995, Us Mob - History, Culture, Struggle: An Introduction to Indigenous Australia, HarperCollins, Sydney.

Nason, D. 2000a, 'Behind the hijacking of Corroboree 2000', The Weekend Australian, 3-4 June 2000, pp.1, 4.

Nason, D. 2000b, ‘Treaty inclusion a “victory” for Clark’, The Australian, 8 December 2000, p.5.

Nason, D. and Saunders, M. 2000, 'Push for treaty “a disgrace”', The Australian, 29 May 2000, p.4.

Nettheim, G. 2000, 'Reconciliation: challenges for Australian law', Australian Journal of Human Rights, vol. 7, no. 1, pp.47-76.

Nossal, G. 2000, 'Symbolism and substance in the surge towards reconciliation' in Grattan, M. (ed), Essays on Australian Reconciliation, Bookman Press, Melbourne.

O’Shane, P. 1994, 'What should Mabo mean?' in Healey, K. (ed), Racism and Reconciliation: Issues for the Nineties, Volume 28, The Spinney Press, Rozelle, NSW.

Pearson, N. 1993, 'Reconciliation: to be or not to be - separate Aboriginal nationhood or Aboriginal self-determination and self-government within the Australian nation?', Aboriginal Law Bulletin, vol. 3, no. 61, pp.14-17.

Pearson, N. 1994, 'Aboriginal law and colonial law since Mabo’ in Fletcher, C. (ed), Aboriginal self-determination in Australia, Aboriginal Studies Press, Canberra.

Pratt, A., Elder, C. and Ellis, C. 2001, 'Papering over the differences': Australian nationhood and the Normative Discourse of Reconciliation' in Kalantzis, M. and Cope, B. (eds), Reconciliation, Multiculturalism, Identities: Difficult Dialogues, Sensible Solutions, Common Ground Publishing, Altona, Victoria.

Reynolds, H. 1991, 'Who is reconciling whom and to what?', Australian Society, June 1991, p.4.

Reynolds, H. 1996, Aboriginal Sovereignty: Reflections on race, state and nation, Allen and Unwin, Sydney.

Reynolds, H. 1998, 'Sovereignty’ in Peterson, N. and Sanders, W. (eds), Citizenship and Indigenous Australians: changing conceptions and possibilities, Cambridge University Press, Cambridge.

Roberts, D. 1993, 'Reconciliation and the Mabo factor', Kaurna Higher Education Journal, vol. 4, pp.16-24.

Roberts, F. 1992, 'Government approach is wrong', Twelve to Twenty-Five, vol. 2, no. 2, pp.4-5.

Saunders, M. 2000, 'Limited support for black seat quota', The Australian, 2 June 2000, p.2.

Saunders, M., Kerin, J. and Rintoul, S. 2000, ‘New backing for Dodson’s treaty’, The Weekend Australian, 27-28 May 2000, p.4. 
Saunders, M. and Nason, D. 2000, 'Howard firm: no black treaty', The Australian, 30 May 2000, p.1.

Saunders, M. and Rintoul, S. 2000, 'Reconciliation body warns on treaty', The Australian, 2 June 2000, p.1.

Scott, E. 1999, 'The preamble - a small step for reconciliation', Journal of Australian Indigenous Issues, vol. 2, no. 3, pp.16-17.

Scott, E. 2000a, 'On the road to being reconciled', The Age, 9 June 2000, p.15.

Scott, E. 2000b, 'The tide has turned', The Australian, 8 December 2000, p.13.

Seas and Submerged Lands Case 1975, 135 CLR 337, 388.

Taylor, K. 2000, 'ATSIC head revives push for a treaty’, The Age, 27 May 2000, p.10.

Walker, J. 1994, 'Autonomy a vital element for uniting the nation', The Weekend Australian, 20-21 August 2000, p.14.

Wilson, J. 1991, 'Reconciliation or whitewash', The Koori Mail, 4 December 2000, p.13.

Wright, T. and Taylor, K. 2000, ‘PM rule out “divisive” treaty’, The Age, 30 May 2000, p.2. 